Understanding Singaporeans

Values, Lifestyles, Aspirations and Consumption Behaviors 
This page is intentionally left blank 


\section{Understanding \\ Singaporeans \\ Values, Lifestyles, Aspirations and Consumption Behaviors}

\section{Kau Ah Keng Tambyah Siok Kuan Tan Soo Jiuan}

National University of Singapore, Singapore

\section{Jung Kwon}

KDI School of Public Policy and Management, South Korea

\section{World Scientific}




\section{Published by}

World Scientific Publishing Co. Pte. Ltd.

5 Toh Tuck Link, Singapore 596224

USA office: 27 Warren Street, Suite 401-402, Hackensack, NJ 07601

UK office: 57 Shelton Street, Covent Garden, London WC2H $9 \mathrm{HE}$

\section{British Library Cataloguing-in-Publication Data \\ A catalogue record for this book is available from the British Library.}

First published 2004

Reprinted 2005, 2006

\section{UNDERSTANDING SINGAPOREANS: VALUES, LIFESTYLES, ASPIRATIONS AND CONSUMPTION BEHAVIORS}

Copyright $\odot 2004$ by World Scientific Publishing Co. Pte. Ltd.

All rights reserved. This book, or parts thereof, may not be reproduced in any form or by any means, electronic or mechanical, including photocopying, recording or any information storage and retrieval system now known or to be invented, without written permission from the Publisher.

For photocopying of material in this volume, please pay a copying fee through the Copyright Clearance Center, Inc., 222 Rosewood Drive, Danvers, MA 01923, USA. In this case permission to photocopy is not required from the publisher.

ISBN 981-238-730-7

Typeset by Stallion Press

Email: enquiries@stallionpress.com 
To Mei, and our sons, Ming and Kang

— Kau Ah Keng

To my wife, Hoyun, and two children, Andrew and Gina, who spent six wonderful years with me in Singapore

- Jung Kwon

To Paul Ananth and our families

- Tambyah Siok Kuan

To my dear mother

- Tan Soo Jiuan 
This page is intentionally left blank 


\section{Acknowledgement}

While we took the lead in writing this book, we would like to thank the many people who have made significant contributions in making this endeavor a success. The National University of Singapore and the Citibank Group have generously funded the values and lifestyles research study that was the foundation for the book. In particular, Bill Glickert and Solomon Huang from the Citibank Group have been very supportive.

We wish to thank the 1540 Singaporeans who have patiently and gallantly offered us insights into their values, lifestyles and consumption behaviors. Without their kindness and cooperation, we would never be able to understand who Singaporeans really are. We would also like to thank Keith Chu Tze Yang, Nguyen Thu Tuyet Mai, Felicia Fong May Leng, Casey Ng Hui Wun, and Toh Li Hiong for helping in the basic data analyses, and Teo Lay Ching and Celia Chia Pin Cheng for their assistance in data collection, transcribing and data analysis, for Chapters 9 and 10 of this book.

The production team has played a significant role in the preparation of this book for publication. We wish to express our appreciation to Ng Pei Sze, Fong Soo Mei, and Nor Azizah bte Mohd Yusof for helping to prepare the initial tables and charts for the book. Finally, we are indebted to the administrative and technical support rendered by the multi-talented and multi-tasking Jothiletchumy d/o Shanmugam.

Kau Ah Keng

Jung Kwon

Tambyah Siok Kuan

Tan Soo Jiuan 
This page is intentionally left blank 


\section{About the Authors}

\section{Dr. Kau Ah Keng}

Dr. Kau is a full professor with the NUS Business School, National University of Singapore. He received his Ph.D. in Business Administration from the London Graduate School of Business Studies, U.K. He previously served as the head of the Department of Marketing, Faculty of Business Administration, National University of Singapore. He was also Vice-Dean of the Faculty of Business Administration and Director of the School of Postgraduate Management Studies in charge of the MBA program. He was a visiting scholar to the University of Michigan, U.S.A. in 1989/90, Tsinghua University of Beijing, China, in 1993, School of Marketing, University of New South Wales in July-September 2003 and Graduate School of Business, Stanford University in October-November, 2003.

$\mathrm{He}$ presently teaches $\mathrm{BBA} / \mathrm{MBA}$ programs at the NUS Business School and also conducts executive development programs for business executives from Singapore, Malaysia, Indonesia, China and the region. He has also served as training and research consultants to various corporations in Singapore and the region.

He has done and supervised many studies on services marketing. He has published extensively in various international journals, including the Journal of Marketing Research, International Marketing Review, Journal of Business Ethics, International Journal of Small Business, Journal of International Consumer Marketing, Tourism Management, Psychology and Marketing, Journal of Travel Research, Social 
Indicators Research and Asia Pacific Journal of Tourism Research. Presently, he is in the editorial advisory boards of Management and Development, Journal of Asia Pacific Marketing and the Singapore Management Review. He has also jointly authored two books: Values and Lifestyles of Singaporeans: A Marketing Perspective (Singapore University Press) and Seven Faces of Singaporeans: Their Values, Aspirations and Lifestyles (Prentice Hall 1998).

\section{Dr. Jung Kwon}

Dr. Jung Kwon is currently an Associate Professor at the KDI School of Public Policy \& Management in Korea. He received his Ph.D. in Marketing from the University of Illinois at Urbana-Champaign in 1996. He had taught at the National University of Singapore before he joined the KDI School in 2002.

His research and teaching interests include Marketing/Business Research, Cross-Cultural Consumer Behavior, Consumer Lifestyles, and New Product Development \& Brand Management. He has been conducting lifestyle studies on Singapore consumers with a team of NUS professors and authored the clustering chapter in the book titled Seven Faces of Singaporeans: Their Values, Aspirations and Lifestyle, where he used various multivariate data analysis techniques including Discriminant Analysis to drive and profile meaningful lifestyle segments of Singaporeans. His research publications have appeared in the international and regional journals including Psychology \& Marketing, Journal of Cross-Cultural Psychology, Journal of International Marketing, Asia-Pacific Journal of Management, and many international conference proceedings.

Before he started his doctoral study in the U.S., Dr. Jung had worked at one of the top advertising agencies in Korea and conducted a series of research projects in many consumer product industries. In Singapore, he was involved in the consulting work with M1, National Library Board, and Techwah.

\section{Dr.Tambyah Siok Kuan}

Dr. Tambyah is currently an Assistant Professor of Marketing at the NUS Business School, National University of Singapore. She received her Ph.D. in Business from the University of Wisconsin-Madison. Prior to entering academia, she was a marketing practitioner in the software industry.

Dr.Tambyah's research and teaching interests include consumption and identity, ethnicity, gender, postmodern consumer research, qualitative 
research methods, cross-cultural consumer behavior and the consumption of place. She has published in the Journal of Consumer Research, Journal of Consumer Marketing, International Marketing Review and Advances in Consumer Research. Dr. Tambyah has taught undergraduate and graduate marketing courses in the United States and Singapore. She has also applied qualitative research methods in consulting projects with numerous companies in Singapore.

\section{Dr.Tan Soo Jiuan}

Dr. Tan (Ph.D, Washington University, USA) is an Associate Professor of Marketing at the National University of Singapore, where she also serves as the Assistant Dean of the NUS Business School. She was elected as the Honorary Treasurer of the Marketing Institute of Singapore and is currently the Chairman of its Board of Studies. Prior to joining academia, Dr. Tan was with the Monetary Authority of Singapore and the Export Credit Insurance Corporation of Singapore

Her research interests are in the areas of international market entry strategies, consumer values and lifestyles, parallel importing, game theoretic applications in marketing, and new product management. She has published in a number of leading international journals including Journal of Business Research, Journal of Business Venturing, Journal of Consumer Marketing, Journal of Cross-Cultural Psychology, Journal of Marketing Communications, European Journal of Marketing, Journal of Global Marketing, International Marketing Review, Public Relations Review, and Small Business Economics. She is also a co-author of two books: Seven Faces of Singaporeans and Competing for Markets: Growth Strategies for SMEs.

Her consulting projects include industry and market studies for major private and public institutions in Singapore and the region. Effectively bilingual, she conducts executive training in both English and Chinese languages. 
This page is intentionally left blank 


\section{Foreword}

As we witness the uncertain economy during the first decade of this century, Singapore is transforming herself so that Singapore will continue her economic growth. The slow economy in Singapore has been the driving force for the fast development of new initiatives such as the government policy on the sales tax and the retirement savings plan, the knowledge-based economy, small and medium sized enterprises, entrepreneurship, etc. To implement a new policy or to launch a new business, one must understand the culture, lifestyles, and mindset of Singaporeans.

In Understanding Singaporeans: Values, Lifestyles, Aspirations and Consumption Behaviors, Kau Ah Keng, Jung Kwon, Tambyah Siok Kuan, and Tan Soo Jiuan have gone through a painstaking exercise by conducting a comprehensive study of the values and lifestyles of different segments of Singaporeans in terms of age, gender, marital status, race, and religion. Specifically, this book offers an in-depth insight regarding Singaporeans' perspective on value orientations, personal values, life aspirations, life satisfaction, leisure activities, media habits, and the Internet usage. In addition, this book highlights the changes in the value system by comparing the survey results obtained in 1996 and 2001.

This book is written with clarity and sincerity. The survey results displayed in this book and their corresponding implications are invaluable to government officials, entrepreneurs, business executives, administrators, as well as the general public. As an expatriate myself, this book helped me 
xiv $\quad$ Understanding Singaporeans

to gain a deeper understanding about Singaporeans. In retrospect, I would have done certain things differently after reading this book.

Christopher Tang Dean and Cycle and Carriage Chaired Professor NUS Business School National University of Singapore

December 2003 


\section{Contents}

Acknowledgement vii

About the Authors ix

Foreword xiii

List of Charts $\quad$ xxi

List of Tables $\quad$ xxiii

1. Introduction and Research Methodology 1

1.1 Background of Study 1

1.2 Survey Research Methodology 5

1.2.1 Questionnaire development 5

1.2.2 Sample selection and data collection $\quad 8$

1.2.3 Data analysis $\quad 8$

1.3 Sample Description 9

1.3.1 Representativeness of sample 9

1.4 Research Methodology for Semi-Structured Interviews 14

1.4.1 Interview guide development 14

$\begin{array}{ll}\text { 1.4.2 Interview data collection } & 14\end{array}$

1.4.3 Interview data analysis 15

1.5 Summary 16 
$\mathrm{xvi}$ Contents

2. Value Orientations

2.1 Family Values

2.1.1 Overview of family values 18

2.1.2 Family values by demographic background 18

2.2 Societal Consciousness 20

2.2.1 Overview of societal consciousness 20

2.2.2 Societal consciousness by demographic background 22

2.3 Status Consciousness 22

2.3.1 Overview of status consciousness 22

2.3.2 Status consciousness by demographic background 22

2.4 Traditionalism 24

2.4.1 Overview of traditionalism 24

2.4.2 Traditionalism by demographic background 24

2.5 Materialism 25

2.5.1 Overview of materialism 26

2.5.2 Materialism by demographic background 26

2.6 Entrepreneurial Spirit 26

2.6.1 Overview of entrepreneurial spirit 26

2.6.2 Entrepreneurial spirit by demographic background 28

2.7 Summary and Implications 28

3. Personal Values and Life Aspirations 31

3.1 Personal Values 31

3.2 Longitudinal Comparison of Personal Values (1996 versus 2001) 32

3.3 Personal Values by Demographic Background 33

3.3.1 Gender 34

3.3.2 Marital status $\quad 34$

3.3.3 Ethnic groups $\quad 35$

3.3.4 Age groups $\quad 35$

3.3.5 Education 37

3.3.6 Personal income 38

3.4 Summary and Implications - Personal Values 39

3.5 Life Aspirations (Things Wanted Most in Life) 40

3.6 Things Wanted Most in Life by Demographic Background 40

3.6.1 Gender $\quad 42$

3.6.2 Marital status $\quad 42$

3.6.3 Age groups 43

3.6.4 Ethnic groups $\quad 45$

3.6.5 Education 46

3.6.6 Personal income 47

3.7 Summary and Implications - Life Aspirations 47 
4. Life Satisfaction

4.1 Satisfaction with Various Aspects of Life 51

4.2 Life Satisfaction: 2001 versus $1996 \quad 52$

4.3 Life Satisfaction by Demographic Background 53

4.3.1 Gender $\quad 53$

4.3.2 Marital status $\quad 54$

4.3.3 Ethnic groups $\quad 55$

4.3.4 Age groups $\quad 55$

4.3.5 Education $\quad 56$

4.3.6 Personal income 57

4.4 Satisfaction with Life in Singapore 58

4.5 Satisfaction with Life in Singapore: 1996 versus 2001

4.6 Satisfaction with Life in Singapore by Demographic

Background $\quad 60$

$\begin{array}{ll}4.6 .1 \text { Gender } & 60\end{array}$

4.6.2 Marital status 61

4.6.3 Ethnic groups $\quad 62$

4.6.4 Age groups 63

4.6.5 Education 64

4.6.6 Personal income 65

4.7 Summary and Implications — Satisfaction with Life 67

5. Media Habits 69

5.1 Television Program $\quad 69$

5.1.1 Television program preferences by demographics 69

5.1.2 Summary and implications - television program 76

5.2 Radio 76

5.2.1 Radio program preferences by demographics $\quad 76$

5.2.2 Summary and implications - radio program 82

5.3 Newspapers 82

5.3.1 Newspaper by demographics $\quad 83$

5.3.2 Summary and implications - newspapers $\quad 89$

$\begin{array}{lll}5.4 & \text { Magazines } & 89\end{array}$

5.4.1 Magazines readership by demographics $\quad 90$

5.4.2 Summary and implications — magazines 94

6. Leisure Activities $\quad 97$

6.1 Sports 97

6.1.1 Sports by demographics $\quad 98$

6.1.2 Summary and implications - sports 103

6.2 Social and Cultural Activities 103

6.2.1 Social and cultural activities by demographics 104 
6.2.2 Summary and implications - social and cultural activities

6.3 Self-Improvement Activities 109

6.3.1 Self-improvement activities by demographics $\quad 110$

6.3.2 Summary and implications - self-improvement activities

6.4 Various Charity, Social Work, and Community Activities 114

6.4.1 Various charity, social work, and community activitiesby demographics

6.4.2 Summary and implications - charity, social work, and community activities

6.5 Travel Activities

6.5.1 Travel activities by demographics

6.5.2 Summary and implications - travel activities 123

6.6 Home Entertainment Activities

6.6.1 Home entertainment activities by demographic background

6.6.2 Summary and implications - home entertainment activities

6.7 Other Activities 129

6.7.1 Various other activities by demographics 130

6.7.2 Summary and implications - other activities 134

7. Internet Usage and Behavior $\quad \mathbf{1 3 5}$

7.1 E-Orientation 135

7.2 Internet Usage 136

7.3 Summary and Implications 152

8. Clustering of Singaporeans 153

8.1 Dimensions of Singaporeans' Value Systems 153

8.2 Identification of Clusters 155

8.3 Lifestyle Activities of Clusters 161

$\begin{array}{lll}\text { 8.3.1 Life satisfaction } & 161\end{array}$

8.3.2 Leisure activities 161

8.3.3 Internet and online shopping behavior 164

8.4 Comparison Between 1996 and 2001 Clusters 164

8.5 Summary and Implications 172

9. Successful Aging In Singapore 173

9.1 Introduction 173

9.2 "Successful Aging" and the Elderly in Singapore 173 
9.3 Research Methodology

9.3.1 The sample for semi-structured interviews $\quad 176$

9.4 Findings

9.4.1 Views about aging

9.4.2 Concerns about aging

9.4.3 Consumption of time and money: family, community, and health

9.5 Summary and Implications

9.5.1 Focusing on family values

9.5.2 Keeping healthy and connected

9.5.3 Moving from working life to retirement

\section{Young Adult Singaporeans}

10.1 Introduction

10.2 "The Young and the Restless"

10.2.1 VALS studies and related findings on young adults

10.3 Research Methodology

10.3.1 The sample for semi-structured interviews

10.4 Findings

10.4.1 Aspirations in life

10.4.2 Importance of personal values 202

10.4.3 Satisfaction with aspects of life in Singapore . 205

10.4.4 Leisure and play

10.4.5 Working in Singapore

10.4.6 Stayers or strayers?

10.5 Summary and Implications

11. Conclusions

11.1 The Study

11.2 Synopsis of the Main Findings

11.2.1 Demographic profile of the respondents

11.2.2 Value orientations

11.2.3 Personal values

11.2.4 Aspirations (Things wanted most in life)

11.2.5 Life satisfaction

11.2.6 Satisfaction with life in Singapore

11.2.7 Media habits

11.2.8 Leisure activities

11.2.9 Internet usage and behavior 
xx $\quad$ Contents

11.3 Clustering of Singaporeans 232

11.4 Qualitative Insights: Elderly Singaporeans 232

11.5 Qualitative Insights: Young Adult Singaporeans 233

11.6 Directions for Future Research 234

$\begin{array}{ll}\text { References } & 237\end{array}$

$\begin{array}{ll}\text { Index } & 241\end{array}$ 


\section{List of Charts}

7.1 Percentage of respondents with access to the internet

7.2 Reasons for not accessing the internet

7.3 Primary internet access points

7.4 Online purchasing experience during the past six months

7.5 Top 10 online purchasing product category

8.1 Changes in values among clusters (Traditional family oriented (16.1\% in 1996 versus 9\% in 2001))

8.2 Changes in values among clusters (New age family oriented (13.9\% in 1996 versus $6.1 \%$ in 2001))

8.3 Changes in values among clusters (Pragmatists

(11.1\% in 1996) versus Modern pragmatists $(10.5 \%$ in 2001))

8.4 Changes in values among clusters (Materialists (14.3\% in 1996) versus Materialistic entrepreneurs $(9 \%$ in 2001))

8.5 Changes in values among clusters (Entrepreneurs $(13.1 \%$ in 1996) versus Entrepreneurial strivers (9.1\% in 2001))

8.6 Changes in values among clusters (Aspirers (18.4\% in 1996 versus $28.3 \%$ in 2001$)$ )

8.7 Changes in values among clusters (Independents (13.1\% in 1996 versus $18.5 \%$ in 2001$)$ ) 
xxii $\quad$ List of Charts

9.1 Importance of personal values (55-64 years, 65 years and above)

9.2 Aspirations in life (55-64 years, 65 years and above) 188

10.1 Aspirations in life (single adults, 25-34 years, $n=192)$

10.2 Importance of personal values (single adults, 25-34 years, $n=192$ )

10.3 Satisfaction with aspects of life in Singapore (single adults, $25-34$ years, $n=192$ )

206

10.4 Satisfaction with aspects of life in Singapore (single adults, $25-34$ years, $n=192$ ) 


\section{List of Tables}

$\begin{array}{lll}1.1 & \text { Variables included in the study } & 7\end{array}$

$\begin{array}{ll}1.2 \text { Sample description } & 10\end{array}$

1.3 Comparing survey data with national statistics 13

2.1 Statements on family values $\quad 18$

2.2 Scores for family values 18

$\begin{array}{lll}2.3 & \text { Family values by demographics } & 19\end{array}$

2.4 Statements on societal consciousness 20

2.5 Societal consciousness scores 20

2.6 Societal consciousness by demographics 21

2.7 Statements on status consciousness 22

2.8 Status consciousness scores 23

2.9 Status consciousness by demographics 23

2.10 Statements on traditionalism 24

2.11 Traditionalism 24

2.12 Traditionalism by demographics 25

2.13 Statements on materialism 26

2.14 Materialism scores $\quad 26$

2.15 Materialism by demographics $\quad 27$

2.16 Statements on entrepreneurial spirit 27

2.17 Entrepreneurial spirit scores 27

2.18 Entrepreneurial spirit by demographics 28 
3.1 Importance of personal values in life

3.2 Longitudinal comparison of personal values (1996 versus 2001)

3.3 Importance of personal values by gender 34

3.4 Importance of personal values by marital status 35

3.5 Importance of personal values by ethnic groups 36

3.6 Importance of personal values by age groups 36

3.7 Importance of personal values by education 37

3.8 Importance of personal values by personal income 38

3.9 Things wanted most in life 41

3.10 Things wanted most in life by gender 42

3.11 Things wanted most in life by marital status 43

3.12 Things wanted most in life by age group 44

3.13 Things wanted most in life by ethnic group 45

3.14 Things wanted most in life by education 46

3.15 Things wanted most in life by personal income 48

4.1 Satisfaction with various aspects of life 52

4.2 Satisfaction with various aspects of life: 1996 versus $2001 \quad 52$

4.3 Satisfaction with aspects of life by gender 53

4.4 Satisfaction with aspects of life by marital status 54

4.5 Satisfaction with aspects of life by ethnic group 55

4.6 Satisfaction with aspects of life by age group 56

4.7 Satisfaction with aspects of life by education 57

4.8 Satisfaction with aspects of life by personal income 58

4.9 Satisfaction with life in Singapore 59

4.10 Satisfaction with life in Singapore: 1996 versus $2001 \quad 60$

4.11 Satisfaction with aspects of life in Singapore by gender 61

4.12 Satisfaction with aspects of life in Singapore by marital status

4.13 Satisfaction with aspects of life in Singapore by ethnic group 63

4.14 Satisfaction with aspects of life in Singapore by age group 64

4.15 Satisfaction with aspects of life in Singapore by education 65

4.16 Satisfaction with aspects of life in Singapore by personal income

5.1 Types of TV program regularly watched (\%) 70

5.2 Types of TV program regularly watched by gender 71

$\begin{array}{lll}5.3 & \text { Types of TV program regularly watched by marital status } & 71\end{array}$

$\begin{array}{lll}5.4 & \text { Types of TV program regularly watched by ethnic group } & 72\end{array}$

5.5 Types of TV program regularly watched by age group 73 
5.6 Types of TV program regularly watched by education

5.7 Types of TV program regularly watched by personal income

5.8 Twelve types of radio program regularly listened to

5.9 Twelve types of radio program regularly listened to by gender

5.10 Twelve types of radio program regularly listened to by marital status

5.11 Twelve types of radio program regularly listened to by ethnic group

5.12 Twelve types of radio program regularly listened to by age group

5.13 Twelve types of radio program regularly listened to by education

5.14 Twelve types of radio program regularly listened to by personal income

5.15 Types of newspaper read

5.16 Types of newspaper by gender

5.17 Types of newspaper by marital status $\quad 85$

5.18 Types of newspaper by ethnic group $\quad 85$

5.19 Types of newspaper by age group 86

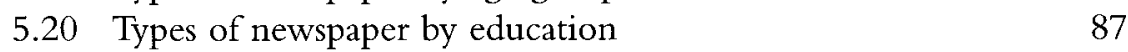

5.21 Types of newspaper by personal income 88

5.22 Types of magazines read 90

5.23 Types of magazines read by gender 90

5.24 Types of magazines read by marital status 91

5.25 Types of magazines read by ethnic group $\quad 92$

5.26 Types of magazines read by age group 93

5.27 Types of magazines read by education 93

5.28 Types of magazines read by personal income 94

6.1 Sports by all respondents: 1996 versus 2001

6.2 Sports by gender 99

6.3 Sports by marital status $\quad 99$

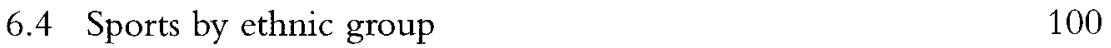

6.5 Percentage of respondents engaged in various sports by age group

6.6 Percentage of respondents engaged in various sports by education

6.7 Percentage of respondents engaged in various sports by personal income 
xxvi $\quad$ List of Tables

6.8 Social and cultural activities by all respondents: 1996 versus 2001

6.9 Social and cultural activities by gender 104

6.10 Social and cultural activities by marital status 105

6.11 Social and cultural activities by ethnic group 106

6.12 Social and cultural activities by age group 106

6.13 Social and cultural activities by education 107

6.14 Social and cultural activities by personal income 108

6.15 Self-improvement activities by all respondents 109

6.16 Self-improvement activities by gender 110

6.17 Self-improvement activities by marital status 111

6.18 Self-improvement activities by ethnic group 111

6.19 Self-improvement activities by age group 112

6.20 Self-improvement activities by education 112

6.21 Self-improvement activities by personal income 113

6.22 Charity, social work and community activities by all respondents

6.23 Charity, social work and community activities by gender

6.24 Charity, social work and community activities by marital status

6.25 Charity, social work and community activities by ethnic group

6.26 Charity, social work and community activities by age group

6.27 Charity, social work and community activities by education

6.28 Charity, social work and community activities by personal income

6.29 Travel activities for all respondents 119

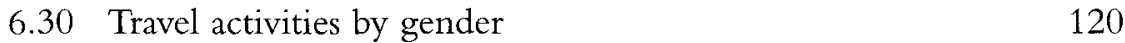

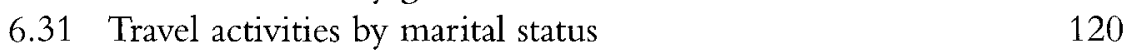

6.32 Travel activities by ethnic group 121

6.33 Travel activities by age group 121

6.34 Travel activities by education 122

6.35 Travel activities by personal income 123

6.36 Home activities by all respondents 124

6.37 Entertainment activities by gender 125

6.38 Home entertainment activities by marital status 125

6.39 Home entertainment activities by ethnic group 126

6.40 Home entertainment activities by age group 127

6.41 Home entertainment activities by education 127 
6.42 Home entertainment activities by personal income

6.43 Other activities by all respondents

6.44 Other activities by gender

6.45 Other activities by marital status

6.46 Other activities by ethnic group

6.47 Other activities by age group

6.48 Other activities by education

6.49 Other activities by personal income

7.1 Statements on E-orientation

7.2 E-orientation by demographics

7.3 Internet access time per day

7.4 Amount of money spent on online purchasing

7.5 Top 10 factors singaporeans are concerned when buying online

7.6 Top four factors influencing singaporeans to buy online

7.7 Internet usage frequency on entertainment: (1) by age, gender, ethnic group and marital status

7.8 Internet usage frequency on entertainment:

(2) by education and occupation

7.9 Internet usage frequency on entertainment: (3) by career lifecycle and personal income

7.10 Internet usage frequency on education: (1) by age, gender, ethnic group and marital status

7.11 Internet usage frequency on banking: (1) by age, gender, ethnic group and marital status

7.12 Internet usage frequency on banking: (2) by education and occupation

7.13 Internet usage frequency on banking: (3) by career lifecycle and personal income

7.14 Internet usage frequency on stock trading: (1) by age, gender, ethnic group and marital status

7.15 Internet usage frequency on stock trading: (2) by education and occupation

7.16 Internet usage frequency on stock trading: (3) by career lifecycle and personal income

8.1 Seven factors and factor loading scores

8.2 Demographic profiles of segments

8.3 Lifestyle activities of clusters

8.4 Lifestyle activities of clusters (media/readership behavior) 
xxviii $\mid$ List of Tables

8.5 Lifestyle activities of clusters (internet and online behaviour) 163

8.6 Comparison between 1996 and 2001 clusters 164

$\begin{array}{lll}9.1 \text { Profile of participants } & 177\end{array}$

9.2 Family values (55-64 years old) 183

9.3 Family values (65 years and above) 184

9.4 Charity/social work/community activities 187

9.5 Lifestyle choices (health) 188

10.1 Findings on young adults 197

10.2 Profile of participants 200

10.3 Family values 203

10.4 Traditionalism 203

10.5 Materialism 204

10.6 Status consciousness 205 